\title{
K-SHELL AND L-SHELL PLASMA SPECTROSCOPY ESPERIMENTS
}

\section{GEORGE CHARATIS}

KMS FUSION, INC. ANN ARBOR, MI

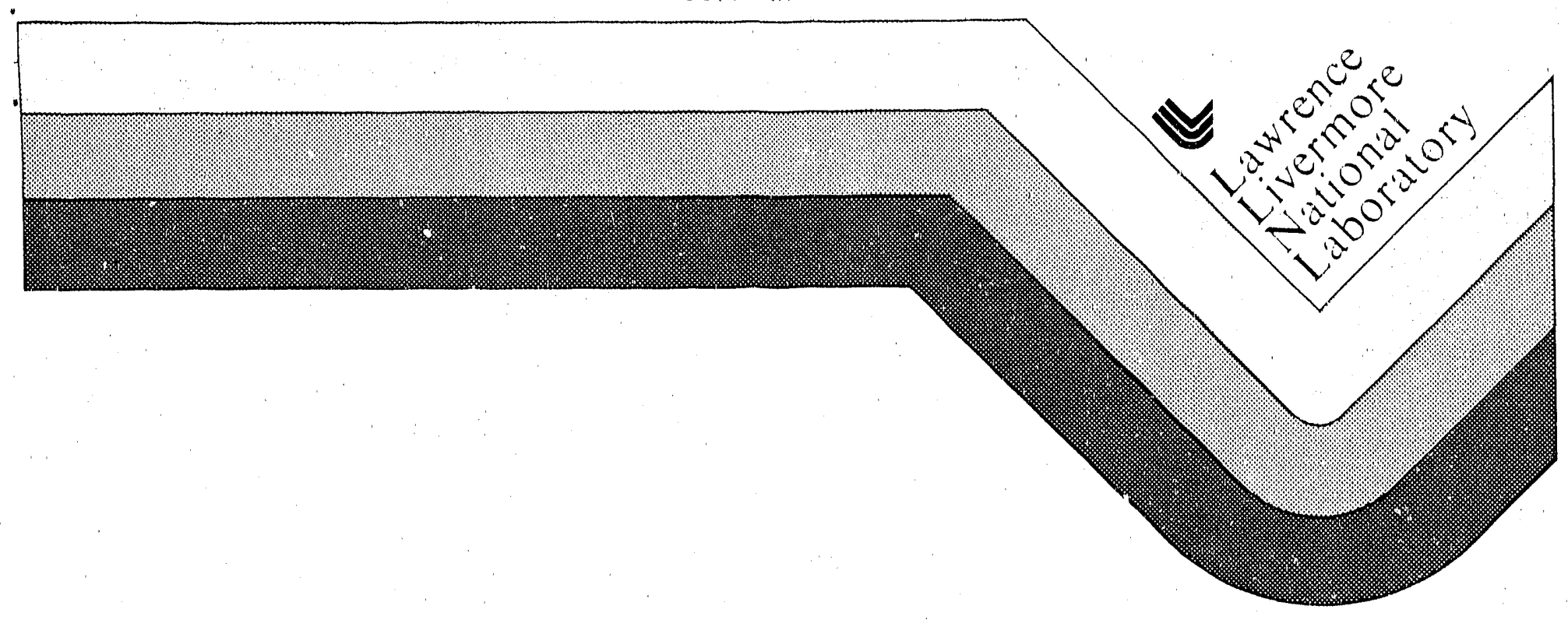

\section{MASTER}


DISC'IAINILR

Work perfurmed under the auspices of the lis. Departmeat of finerg, by Lawrence livermore National laborafury under contract number W-741)5-liN(i-48.

This document was prepared as an account of work sponsored by an agency of the linited Stales Cimernment.

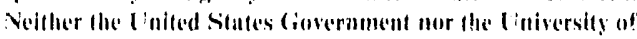
(alifornia nor any of their comployedes, makes any warranty, express or implicd, or assumes any legal liability or responsibility for the accuracy, cempleteness, or usefuluess of any information, apparances, product, or proceses disclosed, or represents that its use would not infringe prisutely annerd

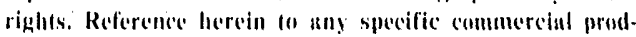
ucts, process, or service by trade name, trademark, manufacfurer, or otherwise, does not neesessurily constitute ar impls its condorstencell, recommendation, ar favoring by the Inited States Ciovernment or the liniversily of california. The views and opinions of authors expressed herein do not necessarily state or reflect these of the l nifed States fiovernment or the Cniversity of california, and slanll anot be used for advertising or product sndarsement purposes. 
UCRL 106064

Final Technical Report

K-Shell and L-Shell Plasma Spectroscopy Experiments

Subcontact B(083590)

by

George Charatis

KMS Fusion, Inc., Ann Arbor Michigan

Detailed atomic level populations in high temperature and dense plasmas have become increasingly important in laser generated plasmas. Certain spectral line ' tensity ratios are densitydependent while others are temperature-dependent. Both can be used to extract information concerning population kinetics and ion level populations. In order to be useful these dependencies must be characterized by independent means. In laser produced plasmas this can be done via holographic interferometry for electron density determinations[1] and via the slope of the $\mathrm{H}$-like free-bound continuum of $\mathrm{K}$-shell lines for electron temperature determinations [2]. The characterization of density- and temperature-dependent L-shell lines can be accomplished in ionization balance experiments in which laser irradiance is varied on targets which contain both $\mathrm{K}$ shell and L-shell emitters. The K-shell free-bound continua provide the local temperature determination while holographic interferometry yields density profile information, from which the temperature and density clependent L-shell lines can be characterized.

The plasma spectroscopy ionization balarice experiments were performed during the latter half of 1989 and into January 1990 on K-shell and L-shell elements. They constitutue a refinement on a previous series of ionization balance expcriments that were performed in 1987 at KMS[3]. The difference between the two sets of experiments consists in the degree of sophistication used in the recording of the time-resolved spectral data. In the earlier, 1987, series, two time-resolving instruments were employed: (1) a streak camera fitted with a low spectrally resolving KAP crystal spectrograph was used to record the time-varying $\mathrm{x}$-ray emission at selected regions of the target plasma plume, and (2) a gated/micro-channel plate(MCP) framing camera spectrometer, also with a KAP crystal, was used to provide spatially resolved spectra at three different times. 
In the present series, 4 gated/MCP framing intensified $x$-ray spectrometrers (FIXS) ( 3 used simultaneously on any one experiment) provided by LLNL, were used to yield simultaneous high, medium and low resolution spectra of the plasma plume, utilizing ADP, Beryl, and KAP crystals, respectively. Electron density was measured using a 4-frame holographic interferometer. Additional target/plasma diagnostics included 3 pinhole cameras ( 2 time-resolved and one time-integrated), one with 3 filtered gated/MCPs yielding 18 timed target images, a spatial- and time-integrating KAP spectrometer, plus the usual energy-on-target and absorbed energy calorimeters and visible streak cameras for pulse length and shape measurements. A further refinement over the 1987 experiments was the use of wide band $(\Delta \lambda=18 \mathrm{~A}$ ) laser irradiation in conjunction with crossed etalon plates designed to induce spatial incoherence in the laser beam, therby smoothing out focused beam hot spots caused by laser coherence. Fig.1 is a a schematic of an axial view of the placement of the spectrometers in the KMS target chamber.

Twenty-five target types, listed in Table 1, were employed to accommodate the different target element emissions and spectrometer sensitivities. $\mathrm{Al}, \mathrm{Mg}, \mathrm{P}$, and $\mathrm{Cl}$, as $\mathrm{K}$-shell emitters, provided information on the electron density and temperature of irradiated targets also containing L-shell emitting spectra of $\mathrm{Mo}, \mathrm{Br} \mathrm{Ge}$ and $\mathrm{Cu}$. A large number of the targets were provided by LLNL. Special composite targets using powder fabrication techniques were fabricated by KMSF. Previously prepared powders of the specified elements (pre-determined composition) were mixed, melted in a furnace, remelted, etc., until the composite was considered well-mixed. The powder mixtures were then tamped into pre-drilled depressions in polystyrene and then shaved at the surface to produce spots with diameters of 50 and $100 \mu \mathrm{m}$, as shown in Fig.2. Also shown in Fig.2 is a so-called 'Bulls-eye' target made by placing a washer of $\mathrm{Mg}$ around the spot, in order to provide added $\mathrm{Mg}$ emission for shots in which electron temperature could be more easily determined via the free-bound continuum of $\mathrm{H}$-like $\mathrm{Mg}$. [4]

The work was performed in five (5) experimental sub-series:

A. Microdot target optimization of $\mathrm{H}$-like and He-like free-bound recombination continuum measurements of the free velocity distribution and electron temperature. $Z$ $=12(\mathrm{Mg})$ and $13(\mathrm{Al})$ 
C. Temporal and spatial measurements of $\mathrm{K}$-shell and L-shell dielectronic satellite lines at high resolution for use as electron density and temperature diagnostics in laser produced plasmas. [5]

D. Experiments to test the feasibility of $\mathrm{x}$-ray lasing schemes in which lines of $\mathrm{Al}$ are used to photo-pump lines of $\mathrm{Fe}[6], \mathrm{Er}[7]$, and $\mathrm{Cu}[8]$.

E. Determination of $\mathrm{T}_{\mathrm{e}}$ for exploding foil $\mathrm{x}$-ray laser targets.

A typical L-shell spectrum of Molybdenum is shown in Fig.3, in which fluorine-like, neonlike, and sodium-like lines of Mo are indicated by $\mathrm{F}, \mathrm{Ne}$, and $\mathrm{Na}$ labels, respectively. As an example of the use of L-shell lines as a measure of density, the $\mathrm{E} 2$ rransition indicated by the line labeled $\mathrm{X}$ is density sensitive[9]. When compared to the $\mathrm{Ne}$-like line $3 \mathrm{~A}$, it can be used as a measure of the plasma electron density, especially under conditions where interferometric measurements of electron density are not practical.

Of a total of 250 targets fabricated, 173 were shot on target, 44 were thin foils and were irradiated on both sides while th : remainder, being thick, were irradiated only from one side. Data reduced at KMS included (a) aser energy on target, (b) absorbed energy by the target, (c) laser pulse shape and length, (d) laser bandwidth, (e) equivalent plane measurements of the irradiated larget spots, ( $f$ ) photographic development of all films, and $(\mathrm{g})$ reconstruction and recording of all (420) holographic interferometer images. Further scanning and reduction of the many spectrograms recorded (estimated at 480), will be carried out at LLNL by LLNL personnel.

\section{References}

[1] Gar. E. Busch, C.L. Shepard, L.D. Siebert, and J.A. Tarvin, Rev. Sci. Instrum. 56, 879, (1985)

[2] C. DeMichelis and M. Mattioli, Nucl. Fusion 21, 677 (1981)

[3] G. Charatis, B.K.F. Young, Gar.E. Busch, C.J. Cerjan, W.H. Goldstein, A.H. Osterheld, T. Phillips, M.D. Rosen, R.E. Stewart, and R.S. Walling, Proc. SPIE 913, (1988)

[4] B.K.F. Young, PhD Dissertation, 291-296 (1988); UCRL 53887

[5] B.K.F. Young et al., Phys. Rev. Letts., 61, 2851, (1988)

[6] J. Nilsen, Phys. Rev. A40, 5440 (1989)

17] Y.T. Lee, Wm. Howard, and J.K. Nash, to appear in JQSRT (Apr or May 1990)

[8] J. Nilsen, LLNL Report UCR.L-102608 (Jan 1990) submitted to Optics Communications

[9] B.K.F. Young et al., Phys. Rev. Letts., 62, 1266 (1989) 


\section{Table}

\section{Target Type}

$\begin{array}{ll}\text { 1. } & \text { Al slab } \\ \text { 2. Al dot/Lexan } \\ \text { 3. Al dot/Lexan } \\ \text { 4. Al dot/Formvar } \\ \text { 5. Al/Al 2-sided } \\ \text { 6. } & 50 \mu \mathrm{m} \mathrm{Al} \mathrm{sq.dot} \\ \text { 7. } & \mathrm{Al} / \mathrm{Ge} / \mathrm{Lexan} \\ \text { 8. } & \mathrm{Al} / \mathrm{NaCl} \text { split } \\ \text { 9. } & \text { Layered Al/NaCl } \\ \text { 10. } & \mathrm{Fe} / \mathrm{Al} \text { 2-slded }\end{array}$

11. Er/Al 2-sided

12. Mg slab

13. $\mathrm{Mg}$ dots

14. $\mathrm{Mo} / \mathrm{Mg}$

15. $10 \% \mathrm{Mo} / 30 \% \mathrm{Mg}$

16. $10 \% \mathrm{Mo} / 30 \% \mathrm{Mg}$ Bullseye

17. $11 \% \mathrm{Mo} / 11 \% \mathrm{Mg}$

18. $2 \% \mathrm{Mo} / 10 \% \mathrm{Mg}$

19. $2 \% \mathrm{Mo} / 10 \% \mathrm{Mg}$ Bullseye

20. $8: 1 \mathrm{Mg} / \mathrm{Mo}$ dot

21. $7 \% \mathrm{Mo} / 7 \%$ P

22. $\mathrm{MgF}_{2} / \mathrm{NaBr}$

23. $10 \% \mathrm{Br} / 40 \% \mathrm{Mg}$

24. $10 \% \mathrm{Br} / 10 \% \mathrm{Mg}$

25. $\mathrm{Mg} / \mathrm{Cu} 2$-sided

\section{Composition}

$1 \mathrm{~mm}$ thick

$50 \mu \mathrm{m}$ dia $\times 147 \mathrm{~nm}$ thick Al on $151 \mathrm{~nm}$ thick Lexan

$100 \mu \mathrm{m}$ dia $\times 158 \mathrm{n}$ thick Al on $151 \mathrm{~nm}$ thick Lexan

$500 \mathrm{~nm}$ thick $\times 530 \mu \mathrm{m}$ dia Al on $100 \mathrm{~nm}$ thick Formvar

$43 \mu \mathrm{m} \times 43 \mu \mathrm{m}$ Al dot on 1 mil Mylar with $53 \mu \mathrm{m}$ dla Al on back

$100 \mathrm{~nm} \mathrm{Al}$ on $50 \mathrm{~nm} \mathrm{Mg}$ on $50 \mathrm{~nm}$ Si on $2 \mu \mathrm{m}$ Al on $125 \mu \mathrm{m}$ Mylar

$23 \mathrm{~nm}$ Al on $34 \mathrm{~nm}$ Ge on $150 \mathrm{~nm}$ Lexan

$70 \times 30 \mu \mathrm{m} \mathrm{NaCl}$ crystal atop $50 \mu \mathrm{m}$ dia Al dot on $150 \mathrm{~nm}$ Lexan

50 layers alternating $15 \mathrm{~nm} \mathrm{Al}$ with $5 \mathrm{~nm} \mathrm{NaCl}$ on $125 \mu \mathrm{m}$ mylar

$35 \times 25 \mu \mathrm{m}$ Fe triangular dot on $5 \mathrm{mil}$ Mylar backed by $50 \mu \mathrm{m}$ dia $\times 12.5 \mu \mathrm{m}$ thick Al dot on opposite side

$50 \times 25 \mu \mathrm{m}$ Er dot on $5 \mathrm{mil}$ Mylar backed by $50 \mu \mathrm{m}$ dia $\times 12.5 \mu \mathrm{m}$ thick Al dot on opposite side

$4.5 \times 6 \mathrm{~mm} \times 15 \mu \mathrm{m}$ thick $\mathrm{Mg}$

$70 \times 70 \mu \mathrm{m} \mathrm{Mg}$ dot on 5 mil Mylar

$50 \mu \mathrm{m}$ dia $\times 90 \mathrm{~nm}$ thick Mo dot on $50 \mu \mathrm{m}$ dia $\times 140 \mathrm{~nm} \mathrm{Mg}$ dot on $150 \mathrm{~nm}$ Lexan

$10 \% \mathrm{Mo} / 30 \% \mathrm{Mg}$ mixture via $\mathrm{MoO}_{3}+\mathrm{MgO}$ powders packed in $50 \mu \mathrm{m}$ dia hole in 5 mil thick polystyrene

$10 \% \mathrm{Mo} / 30 \% \mathrm{Mg}$ mixture via $\mathrm{MoO}_{3}+\mathrm{MgO}$ powders packed in $50 \mu \mathrm{m}$ dla hole in $5 \mathrm{mil}$ thlck polystyrene with $125 \mu \mathrm{m}$ OD Mg washer around OD of hole

$11 \% \mathrm{Mo} / 11 \% \mathrm{Mg}$ mixture via $\mathrm{MoO}_{3}+\mathrm{MgCO}_{3}$ powders packed in $50 \mu \mathrm{m}$ dia hole in $5 \mathrm{mil}$ thick polystyrene

$2 \% \mathrm{Mo} / 10 \% \mathrm{Mg}$ mixture via $\mathrm{MoO}_{3}+\mathrm{MgCO}_{3}+\mathrm{NaHCO}_{3}$ powders packed in $50 \mu \mathrm{m}$ dia hole in 5 mil thick polystyrene

$2 \% \mathrm{Mo} / 10 \% \mathrm{Mg}$ mixture via $\mathrm{MoO}_{3}+\mathrm{MgCO}_{3}+\mathrm{NaHCO}_{3}$ powders packed in $50 \mu \mathrm{m}$ dia hole in 5 mil thick polystyrene with $\mathrm{Mg} 125 \mu \mathrm{m}$ OD washer around $O D$ of $50 \mu \mathrm{m}$ hole

$50 \mu \mathrm{m}$ dia $8: 1 \mathrm{Mg} / \mathrm{Mo}$ on $160 \mu \mathrm{m}$ dia $\mathrm{Mg}$ on $5 \mathrm{mil}$ Mylar

$7 \% \mathrm{Mo} / 7 \% \mathrm{P}$ mixture via $\mathrm{Na}_{4} \mathrm{P}_{2} \mathrm{O}_{7}+\mathrm{Na}_{2} \mathrm{MoO}_{4}$ powder packed in $50 \mu \mathrm{m}$ dia hole in 5 mil thick polystyrene

$50 \mu \mathrm{m}$ dia $\times 110 \mathrm{~nm}$ thick $\mathrm{NaBr}$ dot on $50 \mu \mathrm{m}$ dla $\times 100 \mu \mathrm{m}$ dia $\mathrm{MgF}_{2}$ dot on $150 \mathrm{~nm}$ thick Lexan

$10 \% \mathrm{Br} / 40 \% \mathrm{Mg}$ mixture via $\mathrm{C}_{6} \mathrm{Br}_{6}+\mathrm{MgO}$ powders packed in $50 \mu \mathrm{m}$ dia hole in 5 mill thick polystyrene

$10 \% \mathrm{Br} / 10 \% \mathrm{Mg}$ mixture vla $\mathrm{C}_{6} \mathrm{Br}_{6}+\mathrm{MgO}+\mathrm{C}$ powders packed in $50 \mu \mathrm{m}$ dia hole in $5 \mathrm{mill}$ thick polystyrene

$76 \times 78 \mu \mathrm{m} \mathrm{Mg}$ dot on $5 \mathrm{mil}$ mylar with $53 \mu \mathrm{m}$ dla Cu dot on back side 


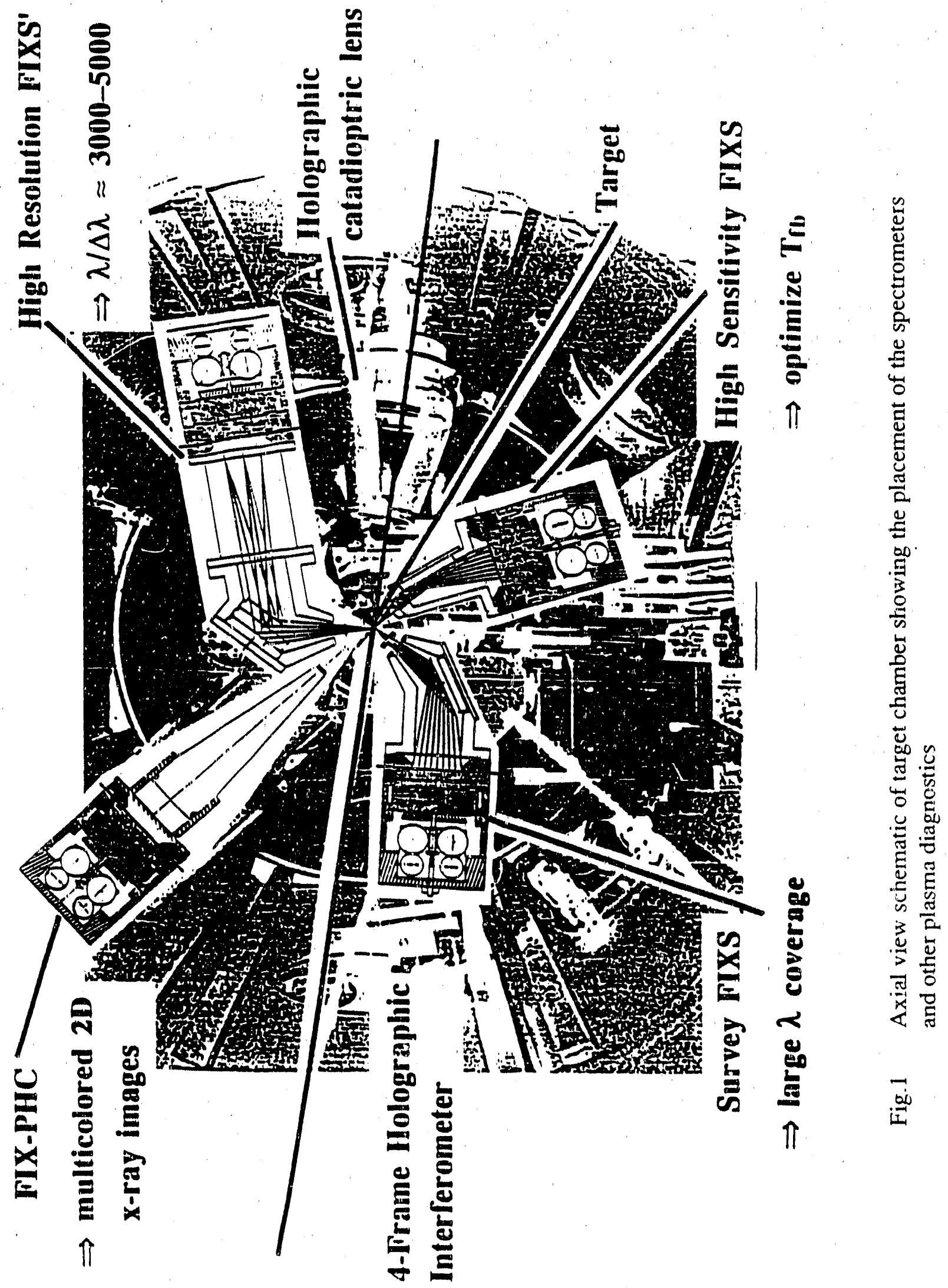



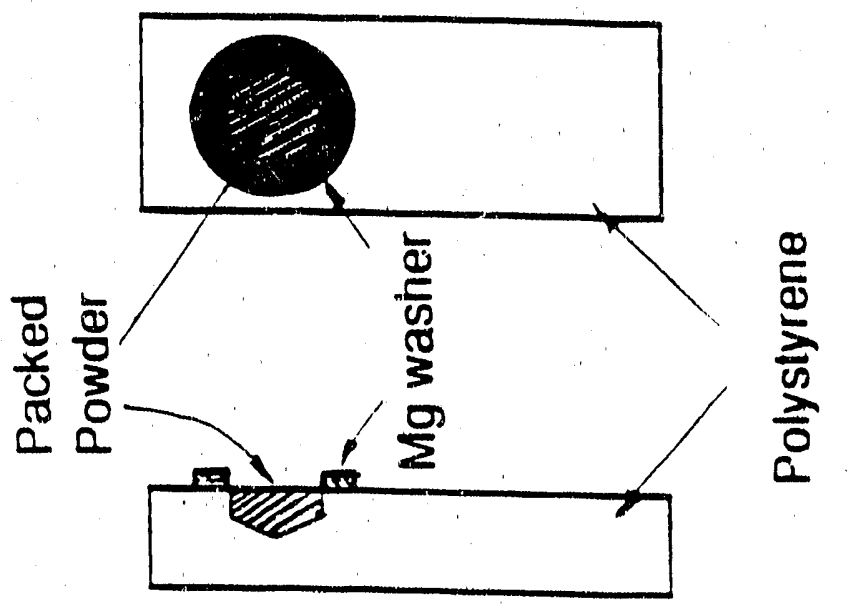

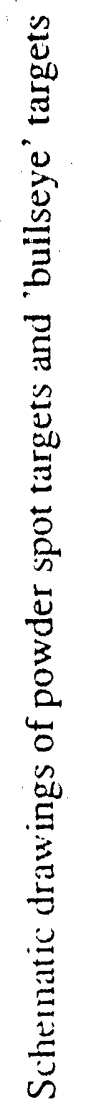

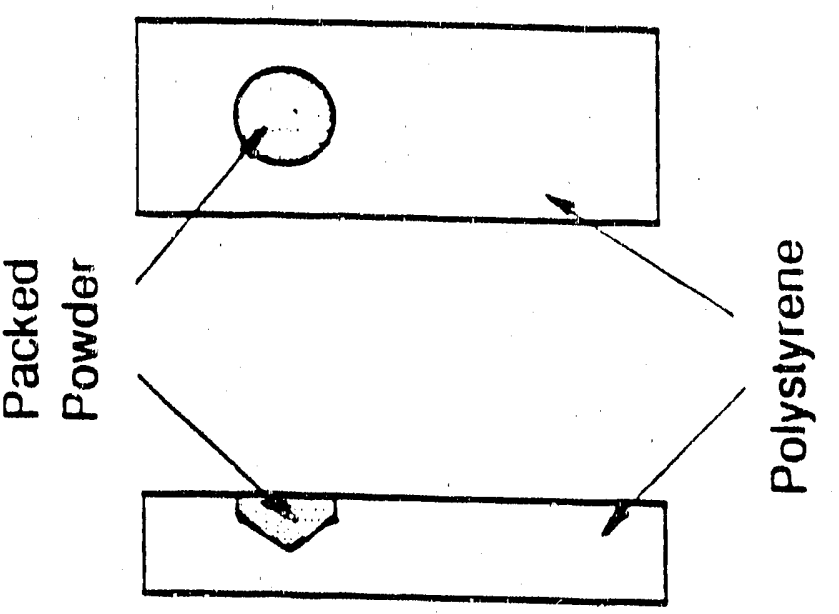

id 


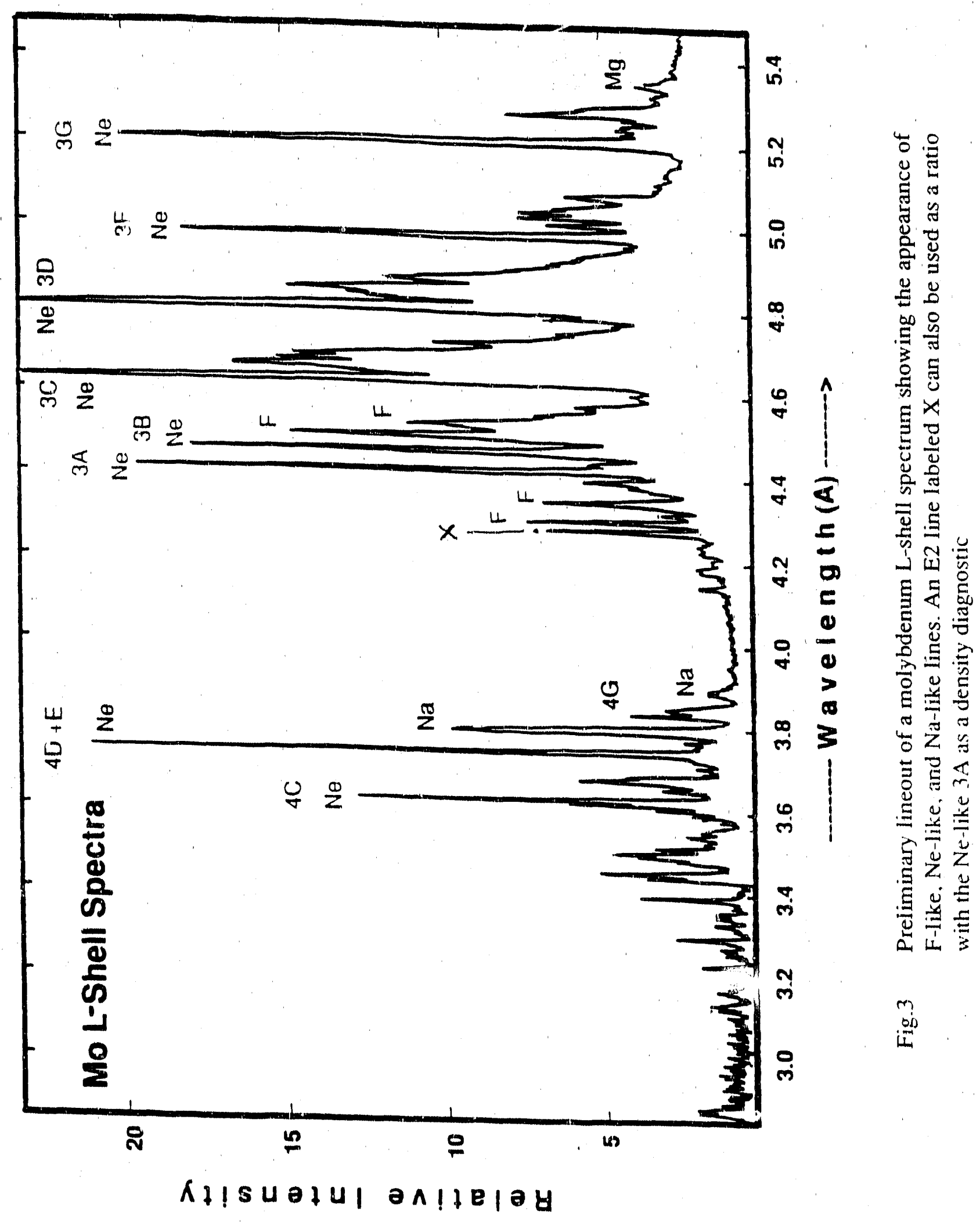



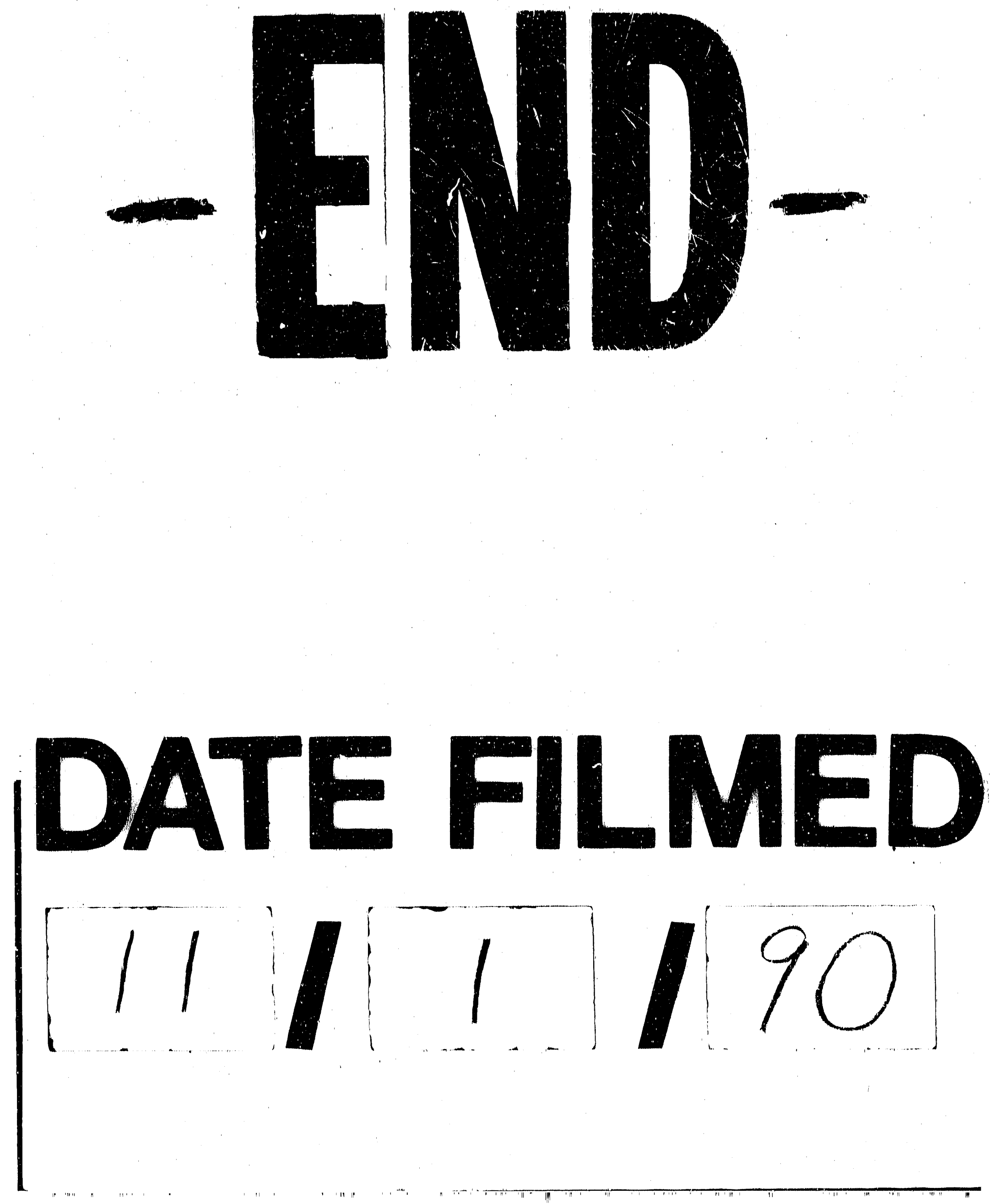
